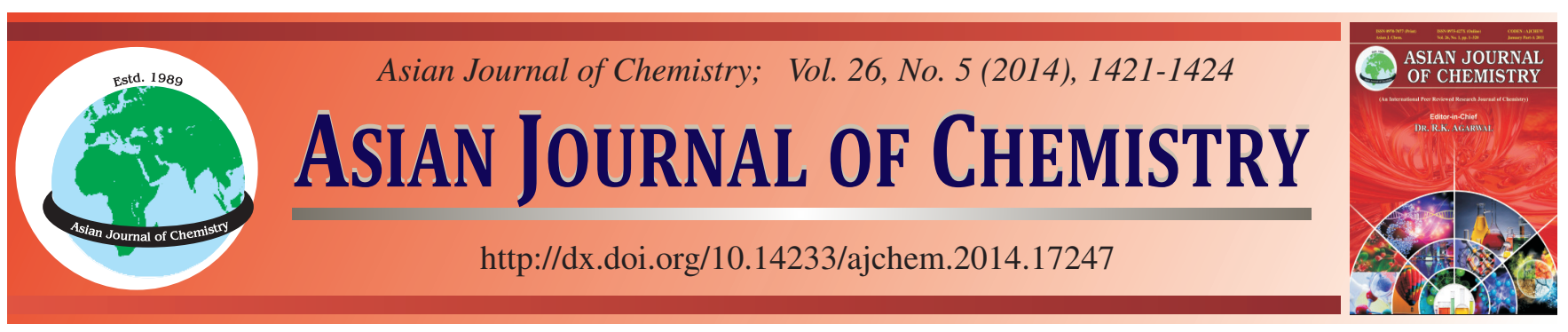

\title{
Study on the Characteristics and Applications of Coal Ash and Slag from Power Plant of Anhui Huaibei Mining Area $\dagger$
}

\author{
XIANGLin ZHANG* and Yun WANG
}

School of Material and Chemical Engineering, Anhui Jianzhu University, Hefei 230031, P.R. China

*Corresponding author: Tel: +86 13705513262; E-mail: zxlaua@163.com

\begin{abstract}
In this study, the compositions and characteristics of circulating fluidized bed combustion (CFBC) desulfurization ash and desulfurization slag from the power plant of Anhui Huaibei Mining Area were analyzed. A kind of composite aluminosilicate cementitious material was prepared through mixing cement with desulfurization ash or desulfurization slag with higher activity ratio and performances in compressive and flexural strength were then tested. The results showed that when the content of desulfurization ash or desulfurization slag was $10 \%$ (wt. \%), the compressive and flexural strength were higher than those of the pure cement paste, but $30 \%$ or more, significantly reduced. Moreover, compared to the pure cement paste, the compressive strength of cement paste added by $5 \%$ of desulfurization slag and $5 \%$ of fly ash was lower, but the long-term compressive strength was increased by $21 \%$.
\end{abstract}

Keywords: Desulfurization ash, Desulfurization slag, Activity ratio, Cementitious materials, Compressive and flexural strength.

ᄂ - - - - - - - - - - - - - - - - - - - - - - - - - - -

\section{INTRODUCTION}

In order to reduce emissions of sulphur dioxide and nitrogen oxides, the supercritical circulating fluidized bed combustion (CFBC) method a clean combustion technology and process was adopted by the thermal power plant of Anhui Huaibei Mining area today. Compared to the fly ash produced by the conventional coal-fired power plant, desulfurization ash and desulfurization slag generated by power plant using limestone as desulphurizer have much better pozzolanic activity and selfhydraulic activity, they can therefore be used as cement or concrete admixtures. The content of calcium and sulphur in desulfurization ash and desulfurization slag produced by foreign coal-fired power plants is extremely high, whose research mainly focused on their hydration characteristics ${ }^{1,2}$. The domestic study on coal ash and slag of power plant is, however, mainly for cement and concrete mineral admixtures such as the preparation of expansion agent and chemical fertilizers, etc. ${ }^{3,4}$.

\section{EXPERIMENTAL}

Preparation of composite aluminosilicate cementing material: Desulfurization ash and desulfurization slag used were produced by burning coal, coal slurry and coal gangue of the circulatory fluidized bed boiler from a power plant in Huaibei mining area. Desulfurization ash was fine and it could all pass through a 100-mesh sieve. Desulfurization slag could pass through the 100-mesh sieve after grinding. Grade 32.5 compound cement produced by Anhui Changfeng Conch Cement co., Ltd. and low calcium fly ash were adopted.

Determination of $\mathrm{SO}_{3}$ in cement: The content of $\mathrm{SO}_{3}$ in cement was $2.36 \%$. In order to guarantee the content of $\mathrm{SO}_{3}$ in composite cementitious material not to exceed the limitation of $3.5 \%$, the content of desulfurization ash or desulfurization slag must be less than $45 \%$.

Preparation of cementitious materials: The raw materials were mixed according to the designed ratio (Table-1), then with $40 \mathrm{~mm} \times 40 \mathrm{~mm} \times 160 \mathrm{~mm}$ mold forming the cement paste, vibrating for $60 \mathrm{~s}$ and then demoulded after 1d. Cured in the curing room to the set age, then flexural strength and pressure strength were measured.

\section{RESULTS AND DISCUSSION}

Component test and analysis of the $\mathrm{CFBC}$ ash and slag: Due to at $850-900^{\circ} \mathrm{C}$ of $\mathrm{CFB}$ boiler, some inert carbon can not be burned completely, leading to the high loss on ignition (LOI) of desulfurization ash and desulfurization slag (Table-2). The LOI of desulfurization ash was higher than that of desulfuri-

†Presented at The 7th International Conference on Multi-functional Materials and Applications, held on 22-24 November 2013, Anhui University of Science \& Technology, Huainan, Anhui Province, P.R. China 


\begin{tabular}{cccccc}
\hline \multicolumn{5}{c}{ TABLE-1 } \\
RATIO OF COMPOSITE SILICATE \\
CEMENTITIOUS MATERIALS
\end{tabular}

zation slag, the reason lies in desulfurization slag stayed at the bottom of CFB boiler for a long time. Since carbon was lamellar structure and polarity, the binding force with other materials was weak ${ }^{5}$. Accordingly, the high LOI could affect the strength and stability of building materials products.

Mining composition characterization of the CFBC coal ash and slag: Quartz, anhydrite, calcite, hematite and free lime were the main crystalline mineral of the desulfurization ash and desulfurization slag (Fig. 1). Furthermore, the XRD pattern of desulfurization ash and desulfurization slag was dispersive bread-like and it shows that desulfurization ash and desulfurization slag contain metakaolin, a kind of amorphous substance, which implies the higher activity. The ordinary coalfired boiler temperature is at $1400-1700{ }^{\circ} \mathrm{C}$. Besides the same minerals with desulfurization ash and desulfurization slag, fly ash also contains mullite, which is a high temperature product. Desulphurizer has not been added in the ordinary boiler, so the content of anhydrite and free lime was low.

Particle morphology and pore structure analysis of the CFBC coal ash and slag: As shown in Fig. 2, the desulfurization ash and desulfurization slag particles are irregular, but the structure of fly ash is dense spherical. The appearance of glass liquid made them shrink into spherical droplets under the effect of surface tension and they bond each other, the surface structure was therefore very compact. The desulfurization ash and desulfurization slag were produced at $850-900{ }^{\circ} \mathrm{C}$ and it was difficult to appear liquid phase at such temperature
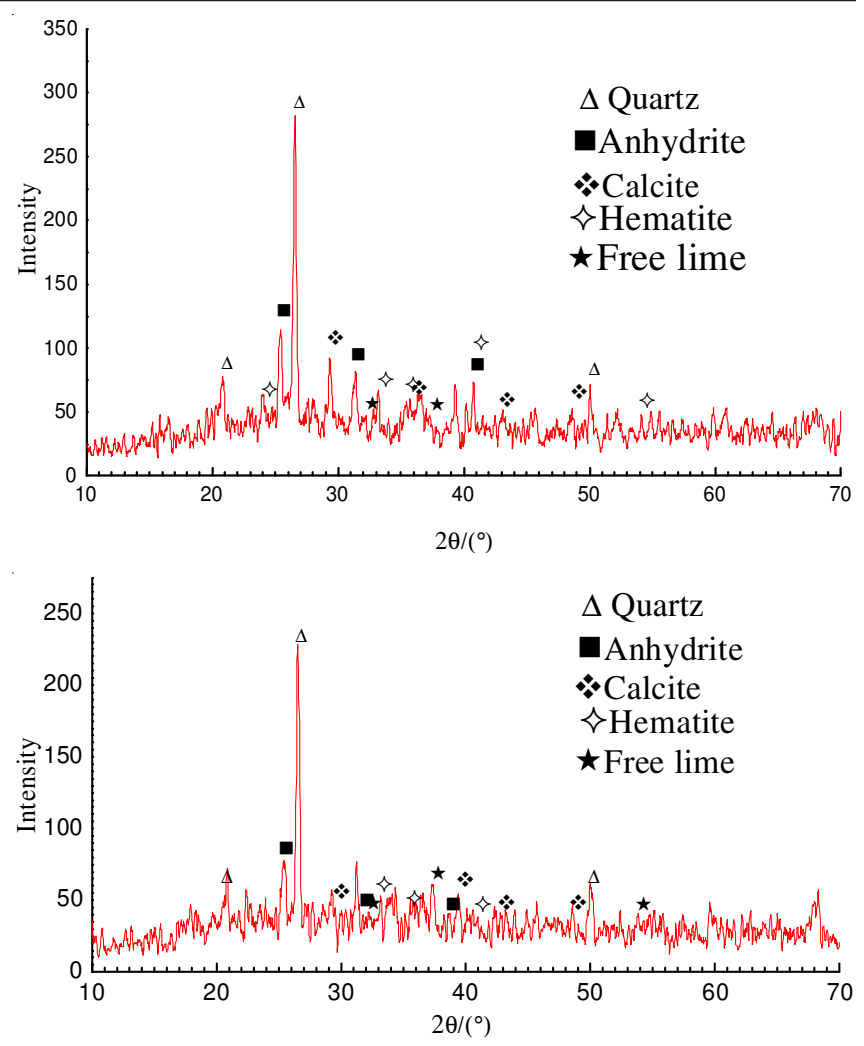

Fig. 1. XRD patterns of desulfurization ash and desulfurization slag

range. Although solid phase diffusion effect could be generated significantly, it could not appear strong densification, so that the desulfurization ash and desulfurization slag showed poriferous and lax structure. The porosity resulted from the generation of $\mathrm{CO}_{2}$ in the process of burning coal and the decomposition of limestone. Their loose pore structure would lead to larger water demand.

Table-3 showed Single-point average pore size of desulfurization ash was less than that of desulfurization slag and multipoint BET specific surface area of desulfurization ash was more than that of desulfurization slag, indicating that the

\begin{tabular}{lccccccc}
\multicolumn{8}{c}{ TABLE-2 } \\
\hline & $\mathrm{SiO}_{2}(\%)$ & $\mathrm{Al}_{2} \mathrm{O}_{3}(\%)$ & $\mathrm{Fe}_{2} \mathrm{O}_{3}(\%)$ & $\mathrm{CaO}(\%)$ & $\mathrm{SO}_{3}(\%)$ & $\mathrm{MgO}(\%)$ & $\mathrm{LOI}(\%)$ \\
\hline Desulfurization ash & 58.43 & 18.09 & 5.32 & 10.52 & 4.87 & 1.05 & 4.40 \\
Desulfurization slag & 48.62 & 22.05 & 5.16 & 10.73 & 4.12 & 1.93 & 3.02 \\
Fly ash & 62.04 & 19.88 & 3.34 & 2.60 & 0.36 & 2.44 & 1.40 \\
\hline
\end{tabular}
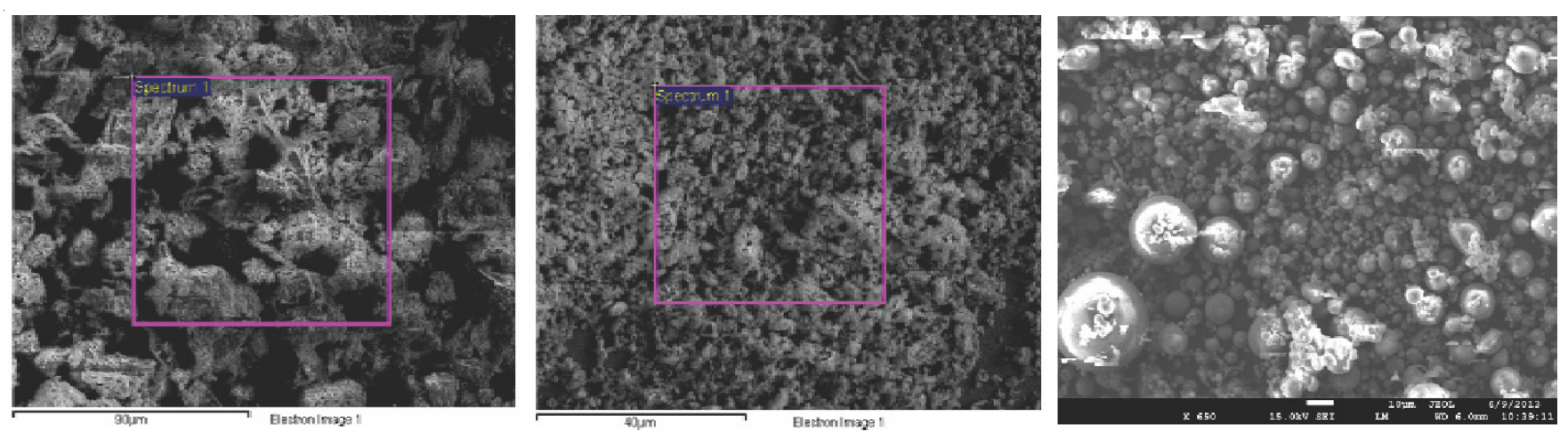

Fig. 2. Scanning electron microscope images of desulfurization ash, desulfurization slag and fly ash 


\begin{tabular}{lcc}
\hline \multicolumn{3}{c}{ TABLE-3 } \\
AVERAGE PORE SIZE AND SPECIFIC SURFACE AREA OF \\
DESULFURIZATION ASH AND DESULFURIZATION SLAG \\
\hline & Single-point & Multipoint BET \\
& average pore & specific surface \\
& size $(\mathrm{nm})$ & $\left.\mathrm{m}^{2} / \mathrm{g}\right)$ \\
\hline Desulfurization ash & 21.11 & 2.94 \\
Desulfurization slag & 36.6 & 2.61 \\
\hline
\end{tabular}

fineness of desulfurization ash was less than that of desulfurization slag. Fineness has great influence on the activity of ash and slag. Therefore, desulfurization ash has greater activity than that of desulfurization slag.

Activity ratio of coal ash and slag of CFBC: Heating reflux method was adopted to measure the activity ratio-Ka of coal ash and slag ${ }^{7}$. The results showed, the activity ratio orders are desulfurization ash (Ka equals to 44.16), desulfurization slag (Ka equals to 34.00) and fly ash (Ka equals to 11.30). Desulfurization ash and desulfurization slag are the highly active materials ( $\mathrm{Ka}$ is greater than $20 \%$ ) and fly ash is moderately (Ka equals to 10-20\%). The determined results of the activity ratio were in line with the trend of fineness roughly.

Performance test and analysis of composite cementitious materials: Flexural and compressive strength of cement paste and composite cementitious materials were shown in Fig. 3. Compared to the flexural strength of $1 \#, 2 \#$ and $3 \#$, we found that, flexural strength orders from strong to weak are composite cementitious materials mixed with desulfurization ash, composite cementitious materials mixed with desulfurization slag and pure cement paste. Contrast to the flexural strength of 3\#, 4\# and 5\#, flexural strength decreased with the increase of desulfurization slag.

Comparing with the compressive strength of 1 \#, 2 \# and 3 \#, after 7 days, compressive strength orders from strong to weak are composite cementitious materials mixed with desulfurization ash, materials mixed with desulfurization slag and pure cement paste, meaning that the main hydration products of composite cementitious materials developed rapidly in early stage due to the high-sulphur and high-calcium desulfurization ash and desulfurization slag. After 28 days, compressive strength orders from strong to weak, however, are the materials mixed with $10 \%$ desulfurization slag, pure cement paste and materials mixed with $10 \%$ desulfurization ash. The reason lie in that the water demand of desulfurization ash was greater than that of desulfurization slag, since the specific surface area of the former was larger than that of the later and the average pore diameter of the former was less than that of the later. However, the water-cement ratio was 0.3 , the composite materials therefore did not have enough hydration water. The low degree of reaction resulted in less calcium silicate hydrate $(\mathrm{C}-\mathrm{S}-\mathrm{H})$ and ettringite, causing poor strength $^{8}$. In addition, because the LOI of desulfurization ash was more than that of desulfurization slag, the high carbon content of desulfurization ash also contributed to the low strength.

In comparison with the compressive strength of $3 \#, 4 \#$ and $5 \#$, after 7 days, it was found that with the increase of desulfurization slag, the compressive strength decreased due to the relatively lower amount of cement clinker, which was the main factors of early ( 28 days ago) intensity. When desulfu-
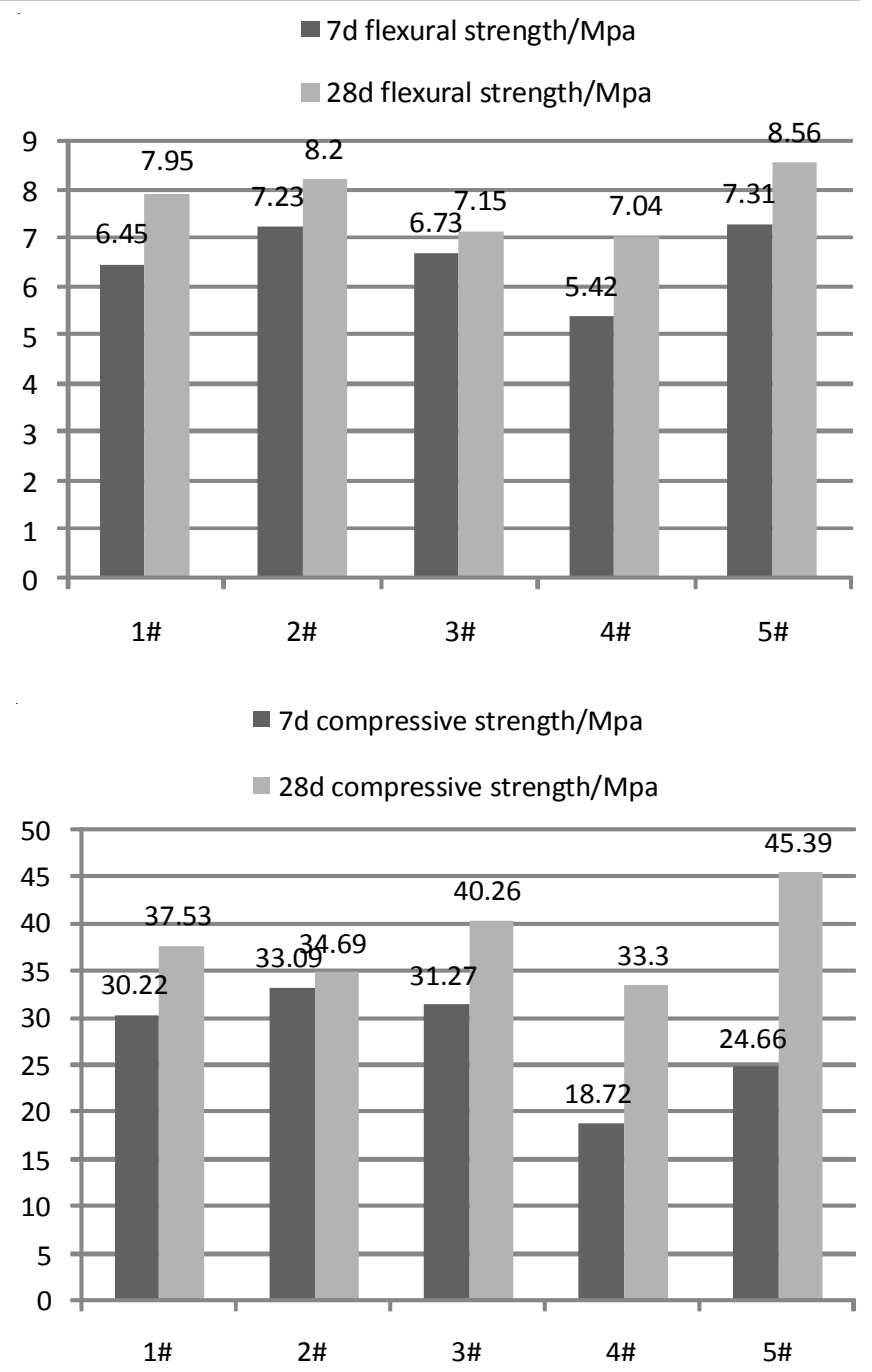

Fig. 3. Flexural and compressive strength of composite cementitious materials

rization slag and fly ash were added into cement, the early strength of composite materials was low, probably because the active $\mathrm{SiO}_{2}$ and active $\mathrm{Al}_{2} \mathrm{O}_{3}$ dissolved slowly. Furthermore, the sulphur and calcium content of fly ash calcium was low, the hydration ability was lower than that of desulfurization slag $^{9}$. After 28 days, compressive strength of composite cementitious materials mixed with desulfurization slag was greatly improved. Specially, when mixed with desulfurization slag and fly ash, strength of the material was increased by $21 \%$ than that of pure cement paste. It showed that desulfurization slag and fly ash had a good synergistic effect and pozzolanic activity of fly ash had been activated at the later hydration process, promoting the secondary hydration reaction. The hydration products filled cementitious material porosity, making the structure be denser and improving the strength.

\section{Conclusion}

The loose structures of desulfurization ash and desulfurization slag from a power plant of Huaibei mining area had significantly different characteristics compared to dense spherical structures of fly ash produced by the ordinary coal-fired boiler. The content of $\mathrm{f}-\mathrm{CaO}$ and II- $\mathrm{CaSO}_{4}$ was higher in desulfurization ash and desulfurization slag and their activity ratio 
was higher, so they could be used as cementitious materials. The activity ratio of desulfurization ash was higher than that of desulfurization slag and the early strength rule of composite cement paste was the same as the activity ratio. Strength of composite cementitious materials decreased with the increasing of desulfurization slag. The early compressive strength of composite cementitious materials mixed with $10 \%$ desulfurization slag was higher than that of the materials mixed with $5 \%$ desulfurization slag and $5 \%$ fly ash, but the later compressive strength rule was opposite. Compared to the pure cement paste, the long-term compressive strength of the materials mixed with $5 \%$ desulfurization slag and $5 \%$ fly ash increased by $21 \%$.

\section{REFERENCES}

1. E. Anthony, L. Jia and Y. Wu, Fuel, 84, 1393 (2005).

2. E.J. Anthony, E.M. Bulewicz, K. Dudek and A. Kozak, Waste Manage., 22, 99 (2002).

3. Y. Chen and Z.Y. Bao, Cement Eng., 19, 10 (2006).

4. G.Z. Zhou and G.Z. Lin, Adv. Environ. Sci., 7, 105 (1999).

5. P. Guo and X.L. Zhao, Value Eng., 30, 63 (2011).

6. I. Schamban, G.E. Shter, A. Shvarzman, G.S. Grader and K. Kovler, Adv. Cement Res., 14, 35 (2002).

7. H.Z. Lian and Z.L. Zhang, J. Build. Mat., 4, 299 (2001).

8. X.N. Tang, Hebei Chem. Ind., 32, 16 (2009).

9. H.Z. He and W.L. Guo, Coal Conversion, 33, 72 (2010). 